\title{
Land Rights Ownership by Foreign Citizens through Nominee Agreement in Tourism Investment in Bali
}

\author{
Made Wiryani, I Wayan Kartika Jaya Utama \\ Faculty of Law \\ University of Warmadewa \\ Denpasar, Indonesia \\ utama.kartika@yahoo.com
}

\begin{abstract}
This study is conducted to describe the impacts arising from the smuggling of agrarian law to avoid losses for investors and the negative impacts on investment evaluation as supporting the efforts of international tourism infrastructure development, particularly in Bali. This research utilizes normative legal method to carry out literature study as it has characteristic and tradition of law science. The approach used in this study is statue approach, case approach and conceptual approach. The result shows that the validity of foreign citizens' ownership of land that is originally owned by Indonesian citizen performed by Notary with notary deed in a formal juridical manner is indeed according to underlying rules, in the sense that the legal status is legitimate. However, it materially violates the provisions of Article 26 paragraph (2) of the Basic Agrarian Law Act (UUPA) as it is an indirect attempt to transfer Land Rights Property from Indonesian citizens to foreign citizens. In conclusion, the ownership of land rights by foreign citizens through nominee in tourism investment violates the provisions of Article 26 paragraph (2) of the UUPA.
\end{abstract}

Keywords - nominee agreement; notary deed; land rights ownership; foreign citizen

\section{INTRODUCTION}

In essence, the human state grows and develop in line with the development of human civilization, meaning that humans will develop their descendants quantitatively in the earth (land). These developments and additions bring logical consequences of the demands of human need for the land as a place of residence, even possible reduction due to natural processes [1]

In the development of international relations, Indonesia has become a member of the Association of South East Asian Nations (hereinafter referred to as ASEAN). In the ASEAN Economic Community (hereinafter referred to as MEA), the principle of land use shall be in accordance with Article 33 paragraph 1 of the 1945 Constitution. National land laws prohibit foreigners from possessing land with Right of Ownership in the territory of Indonesia. The national land law provides that only Indonesian Citizens are entitled to own land with the Right of Ownership in the territory of Indonesia. It means that, land rights is a right which authorizes the holder of his right to use or benefit from the land he or she enters [1].

The common law system lives and develops through oral teaching and oral habits in society. The common law system was implemented and began to develop since the sixteenth century in the United Kingdom. Supported by geographical circumstances as well as ongoing political and social developments. This legal system rapidly expanded beyond the British territory, as in Canada, America, and countries of former British colonies. The common law system forms a major part of the law of many States, especially in countries that were the former colonies or territories of Britain. This is known for the existence of a broad non-statutory law that reflects a consensus of judgment with centuries of history by jurors. Source of law that comes from this habit which then makes this legal system called common law system. This is certainly different from Indonesia with the legacy of the Continental European legal system of the Netherland, as classified as a civil law system that does not adhere to the stare decisis doctrine like common law, i.e., the next judge shall follow the decision of the previous judge's decision in the same fact [2]

In the legal dictionary or Black's Law Dictionary nominee is defined as: [3] "One designated to act for another as his representative in a rather limited sense. It is used sometimes to signify an agent or trustee. It has no connotation, however, other than that of acting for another, in representation of another, or as the grantee of another [4].

The use of nominees is a form of embodiment of an engagement. In Article 1233 of the Civil Code, it is stated "each engagement is to give something, that is to do and to not do something". Hence, the engagement as a form of agreement is a law for the parties involved. In the process of resolving the dispute, an authentic deed which is a written and unlawful evidence provides a tangible contribution to the settlement of cases in a cheap and quick manner [5]. As the strongest and most complete written evidence as stated in the Notarial Deed must be accepted, unless the parties concerned can prove otherwise satisfactorily before the court proceedings [5]. Such provisions are said to be blurred because the legal arrangements already exist, but are unclear or incomplete, so the judge must create a new law as a complement and or substitute for an existing law [6].

Based on the background description of the above problems, the problems in this study are formulated as follows: How is the legal power of land rights ownership by foreign citizens using nominee agreement based on Notarial Deed? 
What is the legal remedy to be made on to control the dispute over the nominee agreement on the control of land rights by foreign citizen's trough Notarial Deed?

This paper discusses the use of nominee agreement in the acquisition of land rights by foreign citizens based on Notarial deed in investment activity to support tourism infrastructure development especially in Bali and legal effort which can be done in dispute settlement of nominee agreement based on Notary Deed so that impacts arise from smuggling law it does not harm the parties to anticipate the negative impacts on investment valuation that support the development of tourism infrastructure at the international level, especially in Bali.

\section{METHOD}

\section{A. Research Type}

Legal science has a distinctive character. The hallmark of law is the normative nature [7]. Normative study should stick to the tradition of the law itself [7]. In accordance with the character and traditions of law, normative research [7] is a hallmark and tradition of law.

\section{B. Case Approach}

Approach to Legal studies used in legal research is statue approach), case approach and conceptual approach [8]. To solve and address problems above research sources that can be distinguished into research resources in the form of primary legal materials and secondary legal materials required [8]. Primary legal materials are legal materials that are authoritative, that is to say, it is authorized [8], consisting of legislation, Judge decisions [8]. Secondary legal materials are all legal publications that are not official documents [8] which includes textbooks, legal dictionaries, legal journals, and comments on court decisions [8]. To obtain the legal materials, the study of the libraries is the way to obtain these legal materials.

\section{RESULT AND DISCUSSION}

\section{A. Trustee and Nominee Agreement}

The term trustee is derived from trust (belief) which has long been known in view of Anglo Saxon legal tradition, trust is created where the absolute owner of property (the settler) passé the legal title in that for the benefit of another person ( the beneficiary) in accordance with terms set out by the settlor [9]. The existence of mutual trust between the manager (trustee) with the party order (settlor or trustor) and the beneficiary [9].

The notion of trustee is a unique institution that is in the system of equity, which involves the existence of three parties, namely [9]: settler/trustor, trustee; beneficiary.

In a trust statement, a settler submits an object to be placed in a trust listed on behalf of or in a trustee's possession [9]. The submission of such object shall not be made by a direct achievement contract that the trustee must undertake to the settler, but to a third party mentioned by the settler in his trust statement. Trustees in common law are holders of the right in law who are entitled to transfer, sell, overburden, pledge, and take any action on the objects provided in such trust [9].

The use of this nominee is a way for foreign citizens to fulfill their desire to indirectly own the land (Self-Land Rights) which in daily practice is to give the possibility for foreign citizens to own land prohibited by UUPA is by way of "borrowing the name "nominee or trustee [10] Indonesian citizen in buying and selling, so that the formal juridical not violate the rules. Nominee Agreement in the field of land in practice is to give the possibility for foreign citizens to have land that is prohibited UUPA is by 'borrowing the name (nominee) [11].

Nominee covenant is said to be an Innominate covenant if a covenant without cause, or that has been made for a false or forbidden cause, has no power and a cause is prohibited, where prohibited by law, or when contrary to good morals or public order. An agreement is said to have no binding legal force if [12]:

- Has no causa;

- The cow is false;

- The law is against the law;

- The law is against the public interest.

In Article 1335 of the Civil Code, the intended "cause" refers to the object or content and purpose of the achievements contained in the treaty itself, not to the cause of which the agreement is made. Because the law only considers the actions of people in society not the background or the reason the parties enter into an agreement [13]. The treaty may be null and void pursuant to Article 1337 of the Civil Code, a forbidden cause, and the injured third party may invalidate this [14]. Authorization is an agreement whereby a person gives power to another, who receives it, to on his behalf organizes a matter [15].

\section{B. The Power of Proof of the Nominee Agreement Made by Notarial Deed}

Notarial deed as described in the Law of Notary Position (UUJN) has authentic character, so that no doubt the perfection (due to the process of making and the authority of its official has been in accordance with the meaning of Article 1870 roped with Article 1868 Civil Code. The power of the law as perfect vowing power (volleding bewijs), since the notarial grosses of the Notary is equal to the verdict of a fixed and definite judgment (inkracht van gewijsde) and has the legal force of executorial [16].

\section{K. Wantjik Saleh asserts [16]:}

According to the law an official deed has the perfect vowing power (volledig bewijs), meaning that if a party advances an official deed, the judge must accept it and assume that what is written in the deed has actually taken place, so the judge may not order the addition proof again.

Proof that includes the stage of determination is also closely related to the principles of Civil Procedure Law. The principles are as follows: 
1) Verhandlungsmaxime principles: The judge is bound by the dispute by the parties and it is the parties that are required to prove, not the Judge.

2) Principle of proof of distribution: The principle of sharing the burden of proof is contained in Article 1865 Civil Code (Article 163 Herzien Indonesis Reglement (HIR), Article 283 Rechtsreglement Buitengewesten ( $R B g$ ).

3) Untersuchungsmaxime priciples: This implies that the egal proofing duties is authorized to the Judge.

It will become a communis opinion that proving means giving the Judge certainty about the existence of events indirectly for the Judge, because the judge must convert the qualifying event which then con-stituir, then the purpose of the settlement is the judge's verdict based on the proof [17].

Article 1868 The Civil Code is the source for the authentic deed of Notary, also constituting the legal basis of existence of Notary deed, with the following conditions [18]:

- The deed must be made by (door) or in front of (ten overstaan) a Public Official.

- The deed must be made in the form prescribed by law.

- Public Officials by or before whom the deed was created shall have the authority to make such deed.

Violation of the provisions of Article 21 paragraph (3) and Article 26 paragraph (2) of the UUPA contains the consequences of cancelation because the law and the land falls on the State. The important difference between the two types of deed is in the value of proof. Authentic deeds have perfect evidentiary value, in the sense that the deed is to be seen as it is, need not be interpreted other than it is written in the deed. A deed under the hand has the power of proof as long as the parties admit it and there is no denial from either party. Based on Article 1320 of the Civil Code and materially binding on the parties making it in accordance with Article 1338 of the Civil Code as an agreement to be fulfilled by the parties (Principles of Pakta Sunt Servanda).

As previously stated, nominee agreement in a formal juridical way to control the Rights Ownership of land of Indonesian Citizens by Foreigners does not violate the rules. However, it materially violates the provision of Article 26 paragraph (2) of UUPA. Violations of UUPA are caused by a lawful cause of such nominee treaties. Regarding the terms of the validity of the agreement, there is a lawful cause. The limitation of a cause is prohibited which is clearly determined that the parties are not free to enter into an agreement if prohibited by law, as contrary to good morality or public order.

\section{Limitation of Notarial Deed to be Null and Void}

An agreement that does not meet the objective requirements, i.e. the object is not certain and the prohibited power, then the agreement is null and void. Concerning the agreement must have a certain object affirmed in Article 1333 of the Civil Code, namely an agreement must have as the subject of a thing that is at least determined its kind is not an impediment that the amount of goods is uncertain. Article 1335 of the Civil Code asserts that a covenant without cause or which has been made for a false or forbidden cause, the treaty has no power, it proves that every treaty must have a kosher cause, but according to Article 1336 of the Civil Code if not stated a cause, but there is a lawful cause or if there is a cause other than that which is stated of his consent but is thus lawful. A cause is prohibited, where prohibited by law, or when contrary to morality or public order.

The intention of cancellation is more directed to the process of formation of the agreement due to law on the cancellation of the agreement is the return on the original position [19], as well as before the conclusion of the agreement. Abolition of the agreement is due to cancellation by the removal of the engagement as intended in Article 1381 of the Civil Code, the dismissal of the agreement because the cancellation clearly removes the existence of the agreement, while the dismissal of the agreement is due to the payment or the accomplishment of merit only removes its own engagement but the existence of the agreement does not remove [19]. The above-mentioned provisions that can be qualified by notarial deed null and void by law, in fact is only an obligation action that must be done by Notary in carrying out his duties of office without any specific object and the lawful cause.

\section{Legal Relationship between Notary Law and the Agents as the Basis for Determining the Civil Sanction}

The Notary must guarantee that the deeds are made in accordance with the rules of the law which have been determined, so that the interests concerned are protected by the deed. With such legal relationship, it is necessary to determine the position of the legal relationship which is the beginning of the responsibility of Notary [20]. The legal relationship between the Notary and the Confrontants cannot be constructed ascertained or determined from the beginning into the form or there has been a breach or an act of law (onrechtmatige daad) or an agreement to perform certain works or representing another person which may be the basis for prosecuting Notary in the form of reimbursement of costs, compensation and interest.

Djojodirdjo describes unlawful acts, comprising [21]:

The term 'unlawful' is attached to both active and passive properties. If he deliberately commits an act that causes harm to others, so deliberately moves, then clearly visible the active nature of the term 'unlawful' is. On the contrary, if he is intentionally silent, he already knows that he must do an act not to harm another person, or in other words, if by passivity alone, that if he does not want to do must violate a requirement, against others, then he has been 'unlawful' without having to move his body. This is the passive nature of the term unlawful'.

The execution of duties of Notary office is the implementation of an esoteric job assignment. Before Notary is sanctioned by civil sanction in the form of cost reimbursement, compensation and interest must be first be proved:

- Loss;

- The loss esults from violations or omissions from Notaries; 
- Such an omission or negligence is caused by an error which may be accountable to the Notary concerned

\section{CONCLUSION}

Nominee Agreement is an agreement involving Foreign Citizens with Indonesian Citizens as a means of acquiring Land Rights Ownership by Foreign Citizens. With the intention of using a nominee agreement, Foreign Citizens may control land as having Ownership Rights on land such as Indonesian Citizens. The Nominee Agreement has not been regulated in Indonesia and is not known in the legal system in Indonesia, particularly the legal system of treaties governed by the Civil Code. For the parties concerned, it is materially infringing, in the sense that its substance is an indirect transfer of rights from Indonesian Citizens to Foreign Citizens and the nominee agreement has no legal power and the effect of the nominee agreement is null and void.

A legal action that can be made to anticipate the occurrence of a dispute over a nominee agreement in which it contains legal acts of transitional ownership of land between Indonesian Citizen and Foreign Citizen is settled by litigation to obtain legal certainty on the nominee deed, because the land law is regulated in Special Act. The legal consequence of a Notary who wishes to make a nominee deed is to incur personal responsibility for the Notary, the accountability of a Notary as a general official in the production of a nominee agreement is the responsibility of administrative, civil, Code of Ethics of Notary and Criminal Position.

\section{ACKNOWLEDGEMENT}

The author would like to thank all the parties who have helped and contributed in the writing of this article, both those who contribute in the form of funding and critical ideas. Hopefully this paper can be useful theoretically and practically for the addition and development of knowledge, especially in the field of legal science.

\section{REFERENCES}

[1] J. A. Hartanto, Hukum Pertanahan Karakteristik Jual Beli Tanah Yang Belum Terdaftar Hak Atas Tanahnya, Surabaya, Laksbang Justicia, 2014.
[2] E. Rajagukguk, Pengelolaan Perusahaan Yang Baik: Tanggung Jawab Pemegang Saham, Komisaris dan Direksi, Artikel Utama pada Jurnal Hukum Bisnis, Volume 26 - No. 3, 2007.

[3] B. H. Campbell, Black's Law Dictionary, Fifth Edition, St. Paul Minn, West Publishing Co.

[4] N. Hasibuan, Perjanjian Nominee Yang Dibuat Untuk Penguasaan Tanah Hak Milik Warga Negara Indonesia Oleh Warga Negara Asing, Desertasi, Program Doktor Ilmu Hukum Fakultas Hukum Universitas Brawijaya, Malang, 2012.

[5] Sjaifurrachman and H. Adjie, Aspek Pertanggung Jawaban Notaris Dalam Pembuatan Akta, Mandar Maju, Bandung. 2011.

[6] A. Rifai, Penemuan Hukum Oleh Hakim Dalam Persepektif Hukum Progresif, Sinar Grafika, Jakarta, 2011.

[7] P. M. Hadjon, Pengkajian Ilmu Hukum, Fakultas Hukum Universitas Airlangga, Surabaya, Tanpa Tahun, Philipus M. Hadjon dan Tatiek Sri Djatmiati, Argumentasi Hukum, Gadjah Mada Universitas Press, Yogyakarta, 2005.

[8] P. M. Marzuki, Penelitian Hukum, Kencana Prenada Media Group, Jakarta, Edisi Pertama- Cet Ketiga, 2005.

[9] Hudson, Alastair, Equity and Trust, 2nd ed, London, Converdish Publishing Ltd, 2002, hlm. 30. Dikutip dalam Anita Dewi Anggraeni Kolopaking, Penyelundupan Hukum Kepemilikan Hak Milik Atas Tanah Di Indonesia, Cetakan ke-1, Alumni, Bandung, 2013.

[10] M. S. W. Sumardjono mengutip dalam Putusan Mahkamah Agung Republik Indonesia Tanggal 27 November 2014 Nomor 1540 $\mathrm{K} / \mathrm{Pdt} / 2014$.

[11] I. M. P. Dharsana, "Akta Notaris/PPAT Sebagai Solusi Komprehensif Penguasaan Tanah Oleh Warga Negara Asing di Bali " makalah yang disampaikan pada Seminar Nasional Universitas Warmadewa, Denpasar, 2006.

[12] J. Satrio, Hukum Perjanjian, Citra Aditya Bakti, Bandung, 1992.

[13] R. Setiawan, Pokok-Pokok Hukum Perikatan, Cet IV, Bina Cipta, Jakarta, 1987.

[14] P. Patrik, Dasar - Dasar Hukum Perikatan, Mandar maju, Semarang, 1994.

[15] Kitab Undang-Undang Hukum Perdata. 1792.

[16] A. A. A. Prajitno, Pengetahuan Praktis Tentang Apa dan Siapa Notaris di Indonesia, Prawira Media Nusantara, Surabaya, 2015.

[17] Mertokusumo, M. S., and Pitlo, A. Bab-bab tentang penemuan hukum. Citra Aditya Bakti. 1993.

[18] H. Adjie, Hukum Notaris Indonesia, Refika Aditama, Bandung, 2008.

[19] A. Y. Hernoko, Hukum Perjanjian Azas Proposionalitas Dalam Kontrak Kormersial, Edisi I, Cetakan ke I, LaksBang Mediatama, Yogyakarta. 2010.

[20] M. Pohan, Tanggugugat Advocat, Dokter dan Notaris, Bina Ilmu Surabaya, 1985.

[21] Djojodirdjo, M. A. M., Perbuatan melawan hukum: tanggung gugat (aansprakelijkheid) untuk kerugian yang disebabkan karena perbuatan melawan hukum. Pradnya Paramita, 1979. 